Federal Reserve Bank of Minneapolis

Research Department Staff Report 295

October 2001

\title{
The Great U.K. Depression: A Puzzle and Possible Resolution
}

\author{
Harold L. Cole* \\ Federal Reserve Bank of Minneapolis \\ and University of California, Los Angeles \\ Lee E. Ohanian* \\ Federal Reserve Bank of Minneapolis \\ and University of California, Los Angeles
}

\begin{abstract}
Between 1913 and 1929, real GDP per person in the UK fell 1 percent, while this same measure of economic activity rose about 25 percent in the rest of the world. Why was Britain so depressed in a decade of strong economic activity around the world? This paper argues that the standard explanations of contractionary monetary shocks and an overvalued nominal exchange rate are not the prime suspects for killing the British economy. Rather, we argue that large, negative sectoral shocks, coupled with generous unemployment benefits and housing subsidies, are the primary causes of this long and deep depression.
\end{abstract}

*We thank seminar participants at UCLA and the Great Depressions of the 20th Century Conference, and Tim Kehoe and Richard Rogerson for helpful comments. We are particularly indebted to Ed Prescott and our discussant, Tom Sargent. We also thank Chris Edmonds and Ron Leung for their research assistance. Ohanian thanks the Sloan Foundation and the NSF for research support. The views expressed herein are those of the authors and not necessarily those of the Federal Reserve Bank of Minneapolis or the Federal Reserve System. 


\section{Introduction}

The United Kingdom entered a major depression shortly after World War I and remained depressed through World War II. This large and persistent depression was unique among the industrialized countries. While many countries suffered depressions in the early 1930s, worldwide economic growth was rapid in the 1920s. For example, UK real GDP per adult fell about 1 percent between 1913 and 1929 while real GDP per capita in the rest of the world rose over 30 percent during this same period. This paper asks why the UK had such a large and persistent depression after World War I. We analyze the UK depression using the same neoclassical methodology we developed in our analyses of the U.S. Great Depression (Cole and Ohanian, 1999, 2001a, 2001b). Our analysis suggests that government policies that reduced the incentive to work are almost surely the cause of the UK's 20-year Great Depression.

We begin by summarizing UK macroeconomic performance during the interwar period. We present data on output, productivity and factor inputs. These data show that all of the decrease in output is due to a large decrease in labor input, reflecting about an 18 percent decrease in hours per worker and an 11 percent decrease in employment. We then evaluate the conventional wisdom that deflationary monetary/exchange rate policy caused the UK depression. We find that the data do not support the monetary/exchange rate explanation; most of the drop in output occurred before the monetary and exchange rate shocks occurred, and the Depression lasted much longer than can be reasonably explained by monetary/exchange rate shocks.

This negative assessment of the conventional monetary explanation leads us to evaluate real shocks. The first real shock we consider is a reduction in the length of the workweek. We 
examine the macroeconomic effects of this restriction with a dynamic, general equilibrium business cycle model to estimate the equilibrium path of the UK economy during the 1920s. While the workweek shock explains the reduction in hours per worker, it does not explain the depression. This is because the model predicts that employment rises substantially in response to this shock and thus offsets much of the decrease in hours per worker. This predicted path of employment differs significantly from the actual large decrease and suggests that some other large shock(s) depressed UK employment. We then present data on two policies that reduced the incentive to work: large increases in unemployment benefits and housing subsidies that raised the cost to workers of relocating from depressed regions. We then present a quantitative-theoretic analysis that suggests that policies that reduced incentives to work may be the key to understanding the UK's 20-year great depression.

The paper is organized as follows. Section 2 summarizes UK macroeconomic performance during the interwar period. Section 3 assesses the standard monetary/exchange rate explanation for the UK's interwar depression. Section 4 presents a dynamic, general equilibrium model we use to assess the macroeconomic effects of the restricted workweek. Section 5 summarizes the quantitative experiments. Section 6 argues that unemployment benefits and the regional concentration of unemployment contributed to the UK interwar depression. Section 7 summarizes the UK unemployment benefits system. Section 8 presents a summary and conclusion.

\section{The UK Economy in the Interwar Period}

This section presents data on the aggregate variables that are central to the neoclassical growth model: output and its components, labor input, and productivity. The source of all 
these data is Feinstein (1972); the appendix describes these data and the other data used in this study in detail. We focus on the 1920s, since this is the decade in which the UK economy does much worse than the world economy.

Figure 1 compares UK output and output for the rest of the world between 1905 and 1937. ${ }^{1}$ These data show that the UK and the rest-of-the-world (ROW) grow at roughly the same rate up to World War I, but diverge sharply thereafter. The UK enters a depression shortly after World War I and remains depressed throughout the interwar period; for example, UK real GDP per adult falls about 1 percent between 1913 and 1929. In contrast, real GDP per capita in the rest of the world rises over 30 percent during this same period. Since the UK depression lasted so long, we also examine the UK output data relative to trend. Output is measured in constant pounds, is divided by the adult population, and is detrended at the historical average growth rate of 1.4 percent per year. It is also normalized to be 100 in the year 1911, so deviations from 100 are deviations relative to trend. Table 1 shows that output fell about 20 percent relative to trend shortly after the war and remained at roughly that level throughout the 1920s. These data suggest that the shocks that depressed the UK economy were UK-specific and were very persistent.

Table 1: UK Detrended Output $(1911=100)$

\begin{tabular}{|l|l|l|l|l|l|l|l|l|}
\hline Year & 1911 & 1919 & 1920 & 1921 & 1923 & 1925 & 1927 & 1929 \\
\hline $\mathrm{Y}$ & 100 & 89 & 82 & 77 & 78 & 80 & 79 & 79 \\
\hline
\end{tabular}

\footnotetext{
${ }^{1}$ The source of the data for the rest-of-the-world is Maddison (1995). This is the sum of real outputs in a number of industrialized countries. The appendix describes the countries included in this measure. We divide UK output by the adult population. Since this measure is not available for all the countries in our rest-of-the-world category, we divide this measure of output by the total population.
} 
We now analyze changes in the components of output. Table 2 shows the shares of output accounted for by consumption, investment, government spending, exports and imports.

Table 2: UK Output Expenditure Shares

\begin{tabular}{|l|l|l|l|l|l|}
\hline Year & $\mathbf{C} / \mathbf{Y}$ & $\mathbf{I} / \mathbf{Y}$ & $\mathbf{G} / \mathbf{Y}$ & $\mathbf{X} / \mathbf{Y}$ & $\mathbf{M} / \mathbf{Y}$ \\
\hline 1911 & 83 & 7 & 8 & 28 & 27 \\
\hline 1919 & 76 & 6 & 18 & 16 & 16 \\
\hline 1920 & 82 & 5 & 11 & 20 & 18 \\
\hline 1921 & 81 & 7 & 12 & 17 & 17 \\
\hline 1923 & 81 & 6 & 10 & 22 & 19 \\
\hline 1925 & 79 & 11 & 9 & 21 & 20 \\
\hline 1927 & 80 & 10 & 9 & 21 & 21 \\
\hline 1929 & 80 & 10 & 9 & 21 & 20 \\
\hline
\end{tabular}

There are no large changes in the fractions of output accounted for by the major domestic GDP expenditure components. The ratio of consumption to output is about .8 in the 1920s, which is roughly unchanged from its prewar average. The ratio of investment to output is somewhat higher in the 1920s than its pre-World War I average. Given that this is a period of declining UK involvement in the British empire, this increase may reflect a reallocation of expenditure from foreign investment to domestic investment. The ratio of government spending to output is roughly unchanged in the 1920s relative to its pre-1920 average. The main difference in the foreign sector is that the shares of exports and imports 
are somewhat lower in the 1920s than before World War I. Trade is roughly balanced during the 1920s, which is consistent with its long-term pre-World War I average. Taken together, these output and expenditure share data suggest that a negative, permanent shock drove the UK economy onto a lower steady state growth path in the 1920s.

To learn more about the nature of this depression, we conduct a growth accounting exercise by decomposing the change in output into the fractions due to changes in total factor productivity (TFP), changes in capital input, and changes in labor input. Since we will be using a model that includes the length of the workweek, we measure TFP using the following Cobb-Douglas technology: $Y_{t}=z_{t} h K_{t}^{\theta} E_{t}^{1-\theta}$,where $z$ is TFP, $h$ is the length of the workweek, $K$ is the capital stock, and $E$ is employment. We use factor shares of 0.3 for capital and 0.7 for employment. ${ }^{2}$

We show averages of these variables for sub-periods, since not all the data are consistently available throughout the period. Table 3 shows that the decrease in output is entirely due to lower labor input. Both TFP and the capital stock grow at about a 1 percent rate during the interwar period. The combined growth in these two variables implies that output should have increased by about 1.3 percent per year during this period. This suggests that

\footnotetext{
${ }^{2}$ Since there is no annual time series of aggregate hours in the U.K., we have constructed an annual measure. We estimated this measure using data from British Historical Statistics and using micro data from individual industries. British Historical Statistics reports measures of average hours per employee for 1873, 1913, 1924 and 1937. These data show that average hours were about 2,700/year in 1873 and in 1913, and were about 2200/year in 1924 and 1937. Annual average hours are available for some of the building trades industries. We also were able to infer an annual average hours per week series between 1914 and 1938 in selected building occupations from weekly wage and average hourly earnings data from the Abstract of Labour Statistics. The occupational data show that hours per week drop sharply between 1918 and 1921. Historical sources claim that the 8-hour day movement and the introduction of paid holidays for manual workers led to a sharp drop in hours worked during this period. To construct an annual hours worked series we assumed that before the war, annual hours were constant at the 1914 level. We assumed that the drop that was observed between 1913 and 1924 occurred in 1920 and 1921, with half the drop coming in each year. Between 1921 and 1924, we assumed that hours were constant at the 1924 level. Since average hours per year are only marginally higher in 1937 (2300/year) we linearly interpolated between these years. We constructed the aggregate measure of hours because there is no consistent annual time series for this variable.
} 
the $\operatorname{shock}(\mathrm{s})$ that depressed the UK economy did not affect either productivity or capital accumulation, but rather operated primarily through labor input.

Table 3: Changes in TFP, Capital and Labor

\begin{tabular}{|l|l|l|l|l|l|}
\hline Years & TFP Growth & Capital Growth & Hours/Worker & Workers/Adult & Hours/Adult \\
\hline Pre-WWI & $0.9 \%$ & N.A. & 2700 & .68 & 100 \\
\hline $1920-38$ & $0.9 \%$ & $1.1 \%$ & 2200 & .61 & 73 \\
\hline
\end{tabular}

Hours worked per adult was about 27 percent below its prewar level. Average hours per worker fell from about 2700 per year before World War I to about 2200 in 1924 and remained at roughly that level in the 1930s. This reduction was partially due to unions' demands for shorter work days and also vacations. Much of this decrease in hours per worker occurred shortly after World War I - average hours for about 40 percent of employees fell from about 55 hours per week to about 47 hours per week in 1919 and 1920.

The workweek restriction sheds light on why hours per worker fell, but makes the employment fall seem even more puzzling. This is because the restricted workweek would tend to increase employment, as households would presumably substitute workers for hours per worker. In contrast, the average fraction of the adult population working falls from about 0.68 prior to World War I to about .60 in 1920 and remains at roughly that level during the interwar period. This indicates that the key to understanding the UK interwar depression is finding a large and persistent shock that depressed employment. We next evaluate some possible candidates for this shock, beginning with monetary/exchange rate shocks. 


\section{The Monetary Explanation of the UK Depression}

The consensus view is that monetary and exchange rate policies were the primary causes of the UK Depression. This section evaluates the monetary/exchange rate explanation but finds that these factors do not plausibly account for the UK interwar depression.

Before presenting this evaluation, we briefly review the standard monetary/exchange rate explanation which is largely a sticky wage/deflation story due to Keynes (1932). He argued that post-World War I deflationary policy depressed the UK economy because nominal wages were imperfectly flexible. According to Keynes, the UK made two policy mistakes: it contracted the money supply too much, and it set the pound/dollar exchange rate at too high a level.

Keynes argued that deflation raised real wages and reduced labor input. He also argued that the exchange rate, which was pegged at $\$ 4.86$ per pound in 1925 , and high real wages reduced British exports. Specifically, he argued that the high real wage prevented the domestic price from falling enough so that British exports were competitively priced with the $\$ 4.86$ exchange rate. Keynes recommended against nominal wage reductions and instead advocated ending deflationary monetary policy and adopting a pegged exchange rate of about $\$ 4.40$ per pound. The crux of Keynes' argument is summarized in the following passages:

"If you fix the exchange rate at this gold parity...you are committing yourself to a policy of forcing down money wages and the cost of living to the necessary extent. We must warn you that this policy is not easy. It is certain to involve unemployment and industrial disputes. If as some people think real wages were already too high a year ago, that is all the worse, because the amount of the 
necessary wage reductions in terms of money will be all the greater....You are intensifying unemployment deliberately in order to reduce wages (p. 253). It is a grave criticism of our way of managing our economic affairs that (wage reductions in and of themselves) seem to any one to be a reasonable proposal" (Keynes 1932, p. 260).

Keynes' monetary/exchange rate story is cited as the leading explanation for the UK Great Depression in several recent analyses, including Hatton (1994), Dimsdale (1981), Moggridge (1972), and Garside (1990). There are four reasons, however, why we find that monetary/exchange rate shocks do not plausibly account for the UK interwar depression. We present each of these in turn.

\section{A. Problem 1: Timing - Depression Occurred Before Deflation}

The first reason is timing: the depression begins well before the monetary contraction. Table 4 shows that most of the decrease in output occurred while the money stock and the price level were still rising: output fell about 18 percent relative to trend between 1918 and 1920, while the money supply and the GDP deflator rose about 30 percent and 43 percent, respectively. ${ }^{3}$ The money stock and price level do not fall until 1921. The fact that almost all of the output decrease occurs before the monetary contraction indicates that unanticipated monetary shocks are not the key factor that depressed the UK economy.

\footnotetext{
${ }^{3}$ The data on the money supply and the deflator are from Friedman and Schwartz (1982).
} 
Table 4: Changes in Real Output, Money, and the Price Level $(1918=100)$

\begin{tabular}{|l|l|l|l|}
\hline Year & Real GDP & Money & Price \\
\hline 1912 & 98.9 & 50.3 & 53.2 \\
\hline $\mathbf{1 9 1 8}$ & $\mathbf{1 0 0 . 0}$ & $\mathbf{1 0 0 . 0}$ & $\mathbf{1 0 0 . 0}$ \\
\hline 1919 & 89.7 & 117.0 & 117.5 \\
\hline $\mathbf{1 9 2 0}$ & $\mathbf{8 2 . 5}$ & $\mathbf{1 2 9 . 8}$ & $\mathbf{1 4 2 . 7}$ \\
\hline 1921 & 77.9 & 127.4 & 126.9 \\
\hline 1922 & 78.8 & 120.4 & 106.9 \\
\hline 1923 & 79.4 & 115.2 & 94.3 \\
\hline 1929 & 79.7 & 117.7 & 92.6 \\
\hline
\end{tabular}

\section{B. Problem 2: Persistence}

The second drawback to the monetary story is persistence: the interwar depression lasted much longer than can be reasonably accounted for by monetary shocks. Monetary business cycle theory predicts that monetary shocks have only transient effects on employment and output. If the monetary shock is identified as either the decline in the money stock or the decline in the price level, then the effects of these shocks should have died out shortly after 1923, when both the money supply and the price level are near their trough values. Alternatively, if the monetary shock is identified as the high real wage as in Keynes' story, then theory suggests the effects of the wage shock should have died out shortly after 1921, which is the only year in the interwar period in which real wages were above their normal 
level. Figure 2 shows a measure of the real wage relative to its normal level, which we measure as the real wage relative to total factor productivity between 1910 and 1938. The figure shows that except for 1921, the real wage relative to productivity in the 1920s is about the same during the post-World War I depression as in the pre-World War I period. These data suggest that monetary shocks do not explain the persistence of the UK depression.

\section{Problem 3: Worldwide Deflation but no Worldwide Depression}

The third drawback to the monetary story is the international evidence: during the 1920s, many other countries experienced significant deflations, but did not suffer major depressions. For example, the U.S. price level fell about 20 percent between 1919 and 1922, but real U.S. per capita output grew over 20 percent between 1919 and 1929. The French price level fell 22 percent between 1920 and 1922, but real French per capita output grew over 25 percent between 1920 and 1929. The fact that other countries had major postwar deflations but also grew substantially indicates that deflation by itself does not explain why the UK economy was depressed during the 1920s.

\section{Problem 4: No Increase in Relative Price of British Exports}

The fourth drawback to the monetary story is that the relative price of British exports did not rise during the interwar period. This fact is inconsistent with Keynes' exchange rate story, which states that the relative price of British exports rose substantially during the interwar period and reduced exports. We measure this relative price by forming the ratio of the price index of UK exports - multiplied by the dollar-pound exchange rate - to the US GDP deflator. This measure shows how the price of UK exports - multiplied by the exchange rate - relative to the domestic US market basket of goods changed during the interwar period: 
$P_{X}^{U K} e / P^{U S}{ }^{4}$ This relative price did not change much during the interwar period. Table 5 shows that this price is only 4.5 percent higher during the 1920s than during the 1890-1911 period. The table also shows the real exchange rate, which is an alternative measure of this relative price. This is the ratio of the price of UK domestic goods - multiplied by the exchange rate - to the price of US goods: $P^{U K} e / P^{U S}$. The table shows that this measure is unchanged between the 1920s and the prewar period. The fact that neither of these relative price measures rose significantly during the interwar depression stands in contrast to the Keynesian view and suggests that an overvalued exchange rate is not the key shock that kept employment low during the interwar period. ${ }^{5}$

\section{Table 5: Real Price of British Exports and the Real Exchange Rate}

\begin{tabular}{|l|c|c|}
\hline Years & $\frac{P_{X}^{U K} e}{P^{U S}}$ & $\frac{P^{U K} e}{P^{U S}}$ \\
\hline $1890-1911$ & 100.0 & 100.0 \\
\hline $1919-1929$ & 104.5 & 100.0 \\
\hline
\end{tabular}

We conclude that the standard monetary/exchange rate story does not plausibly account for the 1920s depression. The timing of the shocks is not right, the shocks are not sufficiently persistent; other countries experienced large deflations, but there were no other persistent depressions; and the price of UK exports relative to US goods did not rise.

This negative assessment of the monetary story leads us to examine the effects of real shocks. We focus on the effect of the cut in the workweek. This allows us to estimate how

\footnotetext{
${ }^{4}$ We use the US deflator since the US was a major trading partner of the UK, and the data are of relatively high quality.

${ }^{5}$ The UK price data are from Feinstein (1972). The US deflator is from Friedman and Schwartz (1982).
} 
much employment should have changed in response to this large policy shock. We conduct this evaluation by developing a dynamic, general equilibrium model with a fixed cost of working which leads to an optimal level of employment and an optimal length of the workweek.

\section{The Model Economy}

This section presents the model economy we use to analyze the effect of the workweek restriction. We begin by summarizing the environment. There is an infinitely lived representative family with many identical members. The household has preferences over a single physical consumption good and household leisure. To focus on the steady state effects of changes in the workweek, we abstract from uncertainty and open economy issues.

Our framework is similar to the Hansen (1985)-Rogerson (1988) formulation in which individuals either work full time or do not work at all. We modify this formulation by explicitly including a fixed cost of working. We choose a simple specification of this cost in our benchmark model such that each household member who works incurs a fixed, linear utility cost each period. ${ }^{6}$ Preferences for the family are

$$
\max \sum_{t=0}^{\infty} \beta^{t}\left\{\log \left(c_{t}\right)+e_{t}[\psi \log (1-\bar{h})-\phi]+\left(1-e_{t}\right)[\psi \log (1)]\right\}
$$

where $c$ denotes household consumption, $e$ is the fraction of family members working, $\bar{h}$ is the length of the workday, and $\phi$ is the fixed cost of working. The resource constraint and the capital accumulation equation are given by

$$
\begin{aligned}
& Y_{t}=\bar{h} K_{t}^{\theta}\left(A_{t} E_{t}\right)^{1-\theta}=C_{t}+I_{t} \\
& K_{t+1}=(1-\delta) K_{t}+I_{t}, K_{0} \text { given }
\end{aligned}
$$

\footnotetext{
${ }^{6}$ The fixed cost could alternatively be modelled as a resource cost or a time cost. The results are not sensitive to this choice, however.
} 
where $Y$ is aggregate output, $K$ is the aggregate capital stock, $E$ is the aggregate employment rate, and $A$ is labor augmenting technological progress, which is given by

$$
A_{t}=(1+\gamma)^{t} .
$$

We conduct the analysis with a stationary version of the model, in which all growing variables are divided by $A_{t}$.

\section{Quantitative Experiments}

We now use this model to analyze the UK macroeconomic performance in the 1920s. The first experiment provides a neoclassical benchmark for the UK economy during the 1920s without the change in the workweek. In this first experiment, both the length of the workweek and the fraction of individuals who work are optimally chosen. We contrast the results of this experiment with a second experiment in which the workweek is restricted to be below the optimal level.

To parameterize the model, we choose the value of the household's discount factor $(\beta)$ so that the interest rate along the steady state growth path is about 7 percent. We choose the leisure parameter $B$ and the fixed cost $\phi$ such that along the steady state growth path the representative household spends about $1 / 3$ of its discretionary time endowment working and that the employment rate in the model is equal to the pre-World War I average rate of 68 percent. We choose the growth rate of labor-augmenting technological progress $(\gamma)$ so that output, consumption, and investment all grow at 1.1 percent, which is the average growth rate of total factor productivity in the data. The depreciation rate $(\delta)$ is 6 percent per year. The parameter $\theta$ is chosen so that labor's share of income is 70 percent of output. 
We compute the perfect foresight competitive equilibrium path of this economy, given an initial condition for the capital stock, which we estimate to be about 12 percent below its prewar steady-state growth path level in 1919.

\section{A. A Benchmark Experiment: Fast Recovery}

This first experiment shows the predicted UK recovery from World War I with no change in the workweek. Table 6 shows the model's predictions for output and employment during the 1920s. The theory predicts that without the workweek restriction, the UK should have recovered quickly after the war - just like the rest of the world - with employment above its steady state level throughout the decade. This prediction of a robust recovery differs significantly from the data. We therefore next assess what fraction of the depression can be accounted for by the one large and permanent labor market shock we have identified so far the workweek restriction adopted shortly after World War II.

Table 6: The Predicted Path of the UK

Recovery from WWII

\begin{tabular}{|l|l|l|}
\hline Year & $\mathrm{Y}$ & $\mathrm{E}$ \\
\hline 1920 & .99 & 1.06 \\
\hline 1922 & .99 & 1.04 \\
\hline 1924 & 1.00 & 1.02 \\
\hline 1926 & 1.00 & 1.02 \\
\hline 1928 & 1.00 & 1.01 \\
\hline
\end{tabular}




\section{B. How Did the "8 Hour Day" Affect the UK Economy?}

Trade unions began negotiating a shorter work day beginning in 1919. The "eighthour day" movement continued through 1920. Aldcroft (1970) reports that about 7 million workers received shorter hours from this movement, and that average hours worked fell about 11 percent - from 54 hours per week to 48 hours per week - between 1919 and 1921, and average hours fell about 15 percent between 1913 and the late 1920s. Aldcroft also notes that there were very few hours reductions in the period after 1921.

We therefore model this decrease in the workweek by exogenously fixing the length of the workweek to be 15 percent less than the optimal steady state level. All other aspects of the experiment remain the same. Table 7 shows the time paths of output and employment relative to their nondistorted steady state levels. The main finding is that employment rises substantially in response to the workweek restriction, as households substitute workers for hours per worker. The steady state employment level with the restricted workweek is about 20 percent above the nondistorted steady state level, and the steady state level of output is about 3 percent lower than its nondistorted steady state level. 


\section{Table 7: The Predicted Path of the UK Economy - \\ Workweek cut 15\% - Constant Fixed Cost of Working}

\begin{tabular}{|l|l|l|}
\hline Year & Y & E \\
\hline 1920 & .95 & 1.24 \\
\hline 1922 & .96 & 1.23 \\
\hline 1924 & .96 & 1.22 \\
\hline 1926 & .97 & 1.21 \\
\hline 1928 & .97 & 1.20 \\
\hline
\end{tabular}

The quantitative effect of the workweek restriction in this model depends on the specification of the fixed cost function. The 20 percent increase predicted by this simple model is probably too high, because the model assumes that the marginal cost of working is constant. We therefore evaluate the robustness of the results to two alternative specifications of the fixed cost function that allow for the fixed cost to rise as the fraction employed rises.

The first alternative specification we use is a quadratic function rather than a linear function. The cost specification is thus modelled as $e_{t}^{2} \mu \phi$ rather than $e_{t} \phi$, where the value of $\mu$ is chosen so that the steady state employment rate without the workweek restriction is identical across the two cost specifications. This quadratic specification predicts that employment should have increased about 18 percent in response to the workweek cut, compared to the 20 percent increase predicted by the linear cost specification.

The second alternative specification is that the cost is linear in the fraction employed, but that the fixed cost rises if the employment rate rises above 68 percent, which was the pre-World War I average. The cost function is therefore given by $e_{t} \phi$ for $e_{t} \leq .68$ and is equal 
to $e_{t} \phi^{*}$ for $e_{t}>.68$. This specification captures the idea that increasing employment above a threshold level requires employing individuals who have higher fixed costs of working. For example, married women with young children probably have a higher fixed cost of working than men. Cogan (1981) estimates that the fixed cost of working for women is about 28 percent of their earnings. We are unaware of comparable estimates for males, but if we assume that the fixed cost of working for men is about one hour per day (this includes commuting time and time to prepare for work) relative to an eight hour workday, then the fixed cost of working for men is about $1 / 8$ or 12.5 percent of their earnings. This is about 50 percent smaller than Cogan's estimate for women. We use these numbers to specify the two different fixed costs in the model. We thus choose a fixed cost for individuals brought in to increase the employment rate above 68 percent to be twice as high as that for other individuals. This specification of differential fixed costs leads the workweek restriction to increase the steady state employment rate in our model by about 10 percent. Table 8 presents the transition path for this experiment.

This analysis of the restricted workweek indicates that the UK employment rate should have increased during the interwar period, although it is difficult to estimate the magnitude of this increase. The most plausible of our three estimates is a 10 percent increase. This finding indicates that another large negative shock to the labor market is responsible for the 10 percent drop in the UK employment rate. Since the ratio of wages to total factor productivity was relatively unchanged between the 1920s and the prewar period, it is unlikely that the shock was changes in unionization or labor bargaining power that would have affected labor demand. Instead, this constancy of the real wage suggests that the shock affected labor 
supply. ${ }^{7}$

Table 8: The Predicted Path of the UK Economy -

Workweek cut $15 \%$ - Higher Fixed Cost for Marginal Family Members

\begin{tabular}{|l|l|l|}
\hline Year & $\mathrm{Y}$ & $\mathrm{E}$ \\
\hline 1920 & .88 & 1.14 \\
\hline 1922 & .90 & 1.12 \\
\hline 1924 & .90 & 1.11 \\
\hline 1926 & .91 & 1.11 \\
\hline 1928 & .91 & 1.10 \\
\hline
\end{tabular}

\section{Unemployment Benefits, the Regional Concentration of Unem- ployment, and the Depression}

This section argues that generous unemployment benefits and the regional concentration of declining UK industrial sectors were key contributing factors to the UK interwar depression. This view stands in sharp contrast to the conventional wisdom, which is summarized by Eichengreen (1987): "Although Keynesians have conceded that some small portion of interwar unemployment may be explicable on these grounds, few have sympathy for the notion that the insurance system contributed significantly to the magnitude of the problem." This conventional wisdom comes from an empirical debate between Benjamin and Kochin (BK) $(1979,1982)$, who presented evidence that unemployment benefits raised unemploy-

\footnotetext{
${ }^{7}$ The relative constancy of the prewar and postwar real UK wage is consistent with the steady state prediction of our model, because the steady state capital/labor ratio is pinned down in the Euler equation for capital by the household's discount rate and the physical depreciation rate on capital.
} 
ment substantially, and a number of critics who empirically criticized BK's findings. ${ }^{8}$ In the appendix we discuss this debate in more detail.

Our approach in addressing this question differs from that used in the previous debate. In contrast to BK's critics, our argument is not based solely on unemployment benefits, but rather focuses on the interaction between these benefits, the regional concentration of declining industries, and government policies that raised the cost of relocation. Moreover, we use a fully articulated general equilibrium model to focus on the incentive effects of unemployment benefits, and we use our model to quantitatively assess the effect of the observed increase in benefits on employment. As we discuss below, this general equilibrium approach leads us to draw a very different conclusion regarding the importance of government policies that changed the incentive to work.

\section{A Summary of the UK Unemployment Benefits System}

Unemployment insurance was introduced in 1911 and was expanded significantly after World War I, in terms of the level of both benefits and coverage. This section presents a summary of UK unemployment insurance, including a discussion of benefit levels, the lack of experience rating, eligibility requirements, and the duration of benefits.

Unemployment benefits were initially provided in the Unemployment Insurance Act of 1911, which extended benefits to $15 \%$ of the workforce. These were primarily manual laborers,

\footnotetext{
${ }^{8}$ BK's main regression of unemployment on the ratio of benefits-to-average-wages and deviation of log output from trend is reproduced here:

$$
\begin{aligned}
U= & .19+18.3 *(B / W)-90.0 *\left(\log \left(Q / Q^{*}\right)\right. \\
& (2.64)(4.46) \quad(-8.30) \\
R^{2}= & .84, \bar{R}^{2}=.82, \mathrm{D}-\mathrm{W}=2.18, S E=1.90 .
\end{aligned}
$$

The JPE (vol. 9, No. 2) published 4 critiques of BK's paper, along with BK's reply. Other critical discussions of BK include Eichengreen (1987) and Hatton (1994).
} 
many of whom were already covered by trade union insurance programs. The benefit level specified in the Act was a fixed amount which depended upon age (16-17, 18-20, and greater than 20) and sex. It was also fairly modest and was eroded by the inflation that took place during WWI. The Act also specified a maximum duration of 15 weeks per year.

Unemployment compensation rose substantially after World War I. This increase was provided through the Out-of-Work Donation, which was available for a short period immediately after WWI and was a noncontributory benefit paid on a relatively generous scale. ${ }^{9}$ It was intended for returning soldiers, but was quickly expanded to cover virtually all adults who registered as unemployed. This was replaced by the Unemployment Insurance Act of 1920, which increased weekly benefits by nearly $40 \%$ relative to the level in the 1911 Act and formally extended coverage to almost all privately employed workers (the main exceptions were agricultural workers and domestics). ${ }^{10}$ The 1920 Act raised the maximum duration of benefits to 26 weeks. This duration limit was not enforced, however, because of high unemployment during 1920: "The contributory basis of the insurance scheme was abandoned within 6 months of the 1920 Act going into operation" (Deacon 1976, p. 14). The duration limit was formally abolished in 1928.

Figure 3 shows unemployment benefits measured as the "replacement rate" - the ratio of unemployment benefits for a married worker with two children to the average wage for manual workers $(B / W)$. The replacement rate rises considerably after the 1920 Act and is

\footnotetext{
${ }^{9}$ The benefits associated with the out-of-work donation were originally set to 24 shillings for men and 20 shillings for women and were increased in December of 1918 to 29 shillings for men and 25 shillings for women. (Source: Burns 1941, p. 3-7.) We have estimated the ratio of benefits to average wages under the donation to have been .47 in 1918 and 1919, and .39 in 1920 .

${ }^{10}$ The benefit in 1911 was a uniform 7 shillings (7s) per week. In 1919 it was increased to 11s per week. In 1920 the benefit was differentiated between men (whose benefit was increased to 15s) and women (whose benefit was increased to 12s). In 1921 benefits for dependents were introduced, and the benefits were frequently changed thereafter in an upward direction, except in 1931. (Source: Burns 1941, p. 3-7.)
} 
around $50 \%$ or higher during much of the interwar period. ${ }^{11}$ This replacement rate almost surely understates the effective relative benefit because individuals tend to experience large decreases in their market wage following a layoff. For example, Jacobson, Lalonde, and Sullivan (1993) show that workers who separate from their jobs during periods of high layoffs initially suffer a 45 percent decrease in earnings and also show that their earnings remain 25 percent below their previous wage five years later. This finding suggests that interwar unemployment benefits may have been roughly comparable to the market wage of displaced workers. Given these high benefit levels and the large number of unemployed, government expenditures on benefits rose from roughly zero before World War I to about 4 percent of GDP by 1930 .

In addition to the high level of benefits, there are other key characteristics of the UK interwar benefits system that significantly changed the incentive to work. We summarize these issues here; BK (1979) discuss them in detail. The first is that there was no experience rating: unemployment insurance contributions were independent of workers' and firms' past histories. The second is that benefits were independent of a worker's past wage. This feature significantly changed incentives for low-skill/low wage workers who tended to have more frequent unemployment spells than high skill/high wage workers. The third feature is that benefits could be collected indefinitely and were payable for unemployment spells as short as one day. These features suggest that both moral hazard and adverse selection may have

\footnotetext{
${ }^{11}$ The levels of employment and unemployment among workers covered by the Act was tracked through the requirement that workers keep an employment/unemployment book. When an insured person became unemployed, he got a book from the employer and "lodged" it with the employment exchange. Upon getting work, the person retrieved the book and gave it to the employer, who affixed stamps for each week of employment. Books expired in July of each year, at which time they were exchanged for new books at the employment exchange.
} 
been pervasive. Modern unemployment insurance systems differ significantly along these dimensions precisely because they try to limit the importance of these incentive problems.

While the UK unemployment insurance system reduced the incentive to work, benefits varied across demographic groups. In particular, groups with lower benefits tended to have lower unemployment rates. For example, BK (1979) document that juveniles - who received lower unemployment benefits - had much lower unemployment rates and that unemployment among married women fell substantially after the October 1931 "Anomalies Legislation" significantly raised married women's contributory requirements.

High unemployment compensation, however, is not the whole story behind the interwar depression. This is because employment recovered to nearly its pre-World War I average in the early 1950s, despite the continuation of high unemployment benefits. ${ }^{12}$ Table 9 shows variations in the replacement rate, the unemployment rate, and employment per adult between 1920 and the 1950s.

The replacement rate falls from about 0.56 in the 1930 s to about $0.38-0.43$ in the 1950s. ${ }^{13}$ This suggests that benefits in the 1950s were lower than those in the 1930s, but roughly comparable to the average for the 1920s. These data indicate that some other factor is required for understanding the difference between the interwar period and the post-World War II period.

In summary, we find that unemployment benefits rose considerably after World War

\footnotetext{
${ }^{12}$ Metcalf, Nickell, and Floros (1982) initially pointed out that benefits remained high during the 1950s, but that unemployment rates were low. BK (1982) responded to this critique by noting changes in the composition of the unemployed and in unemployment reporting. We therefore focus on employment, rather than unemployment.

${ }^{13}$ There is a lack of consensus regarding the benefit-to-wage ratio in the postwar period. Metcalf, Nickell, and Floros (1982) report numbers that are much closer to the interwar level (.43 for 1951-57 and .54 for 1958-65), while Maki and Spindler (1975), using data from the Department of Health and Social Security, report lower numbers.
} 
I, but that employment recovers after World War II, despite the continuation of relatively generous benefits. A successful theory of the UK interwar depression thus requires a general equilibrium that predicts low employment during the interwar period, but high employment during the post-World War II period.

Table 9: Unemployment Insurance and the Labor Market

\begin{tabular}{|l|l|l|l|l|}
\hline & Replacement & Unemployment Rates & \multicolumn{2}{|r|}{ Employment } \\
Year & Ratio $^{14}$ & Ormerod and Worswick & Feinstein & Per Adult \\
\hline 1920 & 0.15 & 3.9 & 2.0 & 0.68 \\
\hline $1921-24$ & 0.35 & 13.3 & 9.1 & 0.60 \\
\hline $1925-29$ & 0.48 & 11.1 & 7.7 & 0.60 \\
\hline $1930-34$ & 0.52 & 19.2 & 13.6 & 0.60 \\
\hline $1935-38$ & 0.56 & 13.1 & 9.4 & 0.63 \\
\hline $1948-54$ & $0.38-0.43$ & - & 1.3 & 0.67 \\
\hline
\end{tabular}

\section{A. Sectoral Shocks and a Consistent Accounting of the Interwar and Post-World War II Periods}

Accounting for the interwar depression requires an additional shock that further reduces the incentive to work during the during the interwar period. Our basic story for this interwar shock is a difference in sectoral shocks between the periods. There were large, negative, sector-specific shocks that hit the UK after World War I, but not after World War II. Given this hypothesis, we conduct two analyses. The first evaluates the steady state effects of

\footnotetext{
${ }^{14}$ These data are from Ormerod and Worswick (1982) for the interwar period and Maki and Spindler (1975) (first number) and Metcalf, Nickell, and Floros (1982) (second number) for the post-WWII period.
} 
unemployment benefits without any sectoral shocks. This provides an estimate of the effects of this policy for the post-World War II period, in which there were no major sectoral shocks. Our main finding is that the model predicts a steady state employment level that is very similar to the post-World War II UK employment level. Given this positive finding regarding the role of unemployment benefits, we then discuss our sectoral shock hypothesis in detail and present evidence supporting this hypothesis.

We begin by evaluating the effects of the unemployment subsidy without sectoral shocks. This requires adding this subsidy to the model developed in section 4 . We do this by specifying that benefits are financed through lump sum transfers and are paid proportionately to the fraction of family members who do not work. The representative household therefore maximizes equation (1) subject to the following period budget constraint:

$$
w_{t} e_{t}+r_{t} k_{t}+T_{t}+s_{t}\left(1-e_{t}\right)-c_{t}-x_{t} \geq 0 .
$$

This budget constraint states that wage income $\left(w_{t} e_{t}\right)$ plus capital income $\left(r_{t} k_{t}\right)$ plus lump sum transfers $\left(T_{t}\right)$ plus family unemployment benefits $\left(s_{t}\left(1-e_{t}\right)\right)$ are sufficient to finance consumption $\left(c_{t}\right)$ and investment $\left(x_{t}\right)$.

Unemployment benefits reduce employment in our model by subsidizing non-market activities. The first order condition that governs the fraction of family members working shows that the subsidy reduces employment by reducing the market wage rate net of the subsidy:

$$
\psi \log (1-\bar{h})-\phi=u_{c t}\left(w_{t}-s_{t}\right) .
$$

Estimating the impact of the subsidy requires choosing the rate of unemployment benefits $\left(s_{t}\right)$. We choose the benefit rate so that in the steady state the total value of benefits 
in the model $\left(s_{t}\left(1-e_{t}\right)\right)$ is equal to the total amount of benefits paid in the data, which is about 4 percent of GNP. Given this value of the subsidy, it is straightforward to calculate the impact of the subsidy on employment. This is because the steady state capital-labor ratio is unaffected by the subsidy, which implies that the steady state wage rate is also unaffected. This in turn implies that the marginal utility of consumption must rise to offset the subsidy. Given our preference specification of log utility in consumption, and separability between consumption and leisure, it follows that the percentage decrease in the steady state employment rate is equal to the percentage decrease in the wage net of the subsidy. Therefore, our model predicts that the observed increase in unemployment benefits reduces steady state employment about 10 percent.

Given our estimates of the effect of the restricted workweek and the effect of unemployment benefits, we now use the model to estimate how much employment should have changed after World War II. We find that our model predicts that the post-World War II employment rate is very close to the data: 0.68 in the model, compared to 0.67 in the data. This prediction reflects the roughly offsetting effects of the restricted workweek and unemployment benefits. The restricted workweek drives employment up about 10 percent, while unemployment benefits drive employment down by the same amount. This estimate, reflecting the combined affects of the workweek restriction and unemployment benefits, suggests that the theory may explain why the employment rate in the 1950s was about the same as it was before World War I.

However, the sharp difference between interwar and post-World War II employment indicates that benefits are only part of the story. We therefore discuss how large, negative sectoral shocks could have further reduced the incentive to work during the interwar period 
relative to the post-World War II period. We discuss this issue in the spirit of Ljungqvist and Sargent (1998).

These authors show how unemployment insurance can lead to changes in unemployment over time because of changes in the marginal value of unemployment benefits. Ljungqvist and Sargent develop a model in which the marginal value of a given level of unemployment benefits depends on the relative volatility of the shocks to worker productivity. During periods of high volatility a relatively large fraction of workers receive large negative shocks to their productivity. This led those workers receiving negative shocks to prefer unemployment to retaining their job at the lower wage. The marginal value of unemployment benefits during these periods is thus relatively high. Alternatively, relatively few workers will experience large negative shocks to their productivity during low volatility periods. Thus, the marginal value of unemployment benefits during these low volatility periods is low. Ljungqvist and Sargent argue that this model - together with their estimates of larger, negative shocks in the post-1970 period - can explain why European unemployment was low in the 1950s and 1960s, but high after the 1970s, despite the fact that unemployment compensation was about the same in these two periods.

It follows that the Ljungqvist and Sargent theory predicts that unemployment would be higher after World War I than after World War II - despite similar benefit levels - if the variance of idiosyncratic shocks to human capital was higher during the earlier period. There are considerable data that are consistent with this view. In particular, there were large, negative sectoral shocks to British industries immediately after World War I that would be expected to drive down the value-marginal products of the workers in these sectors and thereby increase the marginal value of unemployment benefits. Moreover, these negative 
shocks were regionally concentrated, and government-subsidized housing policies that raised the cost of worker relocation raised the marginal value of these benefits even further. We now discuss these post-World War I negative sectoral shocks.

A number of Britain's "staples" industries - including coal, steel, and textiles - declined significantly after World War I. This decline was primarily caused by large decreases in exports. For example, Alford (1981) notes that coal exports fell almost 70 percent between 1913 and 1921. These reductions in exports are likely due to Britain's loss of comparative advantage in producing these goods. This loss of comparative advantage reflects post-World War I British productivity decreases, postwar productivity growth in competing countries, and higher world trade barriers.

Regarding productivity, labor productivity in the coal industry between 1920-29 was only 3 percent higher than in 1912, after correcting for the 15 percent decrease in the workweek. Some researchers (e.g., Alford, 1981) argue that productivity decreases were caused by industry conflict. There were two major coal strikes in 1921 and 1926. After correcting for the shorter post-World War I workweek, labor productivity fell about 25 percent and 38 percent, respectively, relative to its 1912 level, during these two years. ${ }^{15}$

Regarding the effects of trade barriers and foreign competition on British exports, Alford (1981) cites increased competition facing the staples industries and tariff protection which closed previously open markets. Youngson (1967) cites the loss of Russian markets and competition from Poland for sales to Scandinavia as adversely affecting the coal industry during the 1920s. Youngson also discusses how Britain's textile industry was adversely

\footnotetext{
${ }^{15}$ These figures were computed using data in Mitchell and Deane (1962). The data are measured as output per worker. The postwar data are corrected for the 15 percent decrease in the workweek, but are not corrected for normal trend productivity growth.
} 
affected by increased protectionism by China, Japan and India, and by textile sales from these countries into Britain's other export markets. Aldcroft (1986) notes that cotton textile exports fell by more than 50 percent between 1913 and 1922. These large reductions in export demand suggest that the workers in these sectors suffered negative shocks to their value-marginal productivities.

The contraction of these export markets coincided with high unemployment. Aldcroft (1986) notes that manufacturing, mining and construction accounted for about $45 \%$ of British employment in 1929, but accounted for about $75 \%$ of all unemployment that year. Table 10 shows that unemployment in a number of industries in these sectors was higher than the aggregate unemployment rate.

The concentration of unemployment in these declining sectors indicates that the marginal value of unemployment benefits was relatively high during the interwar period for a large fraction of British workers. Another key factor that raised the marginal value of benefits is the regional concentration of the declining industries, combined with government housing subsidies that raised the cost of moving.

Government housing and rent subsidies raised the marginal value of benefits even further by raising the cost to workers of relocating to sectors with better employment opportunities. Many of the declining industries were highly concentrated in Northern England, while the new, growing industries were concentrated in the Midlands. For example, Aldcroft (1986) reports that 1929 unemployment rates ranged from a high of 18.8 percent in Wales, which was dominated by the coal industry, to a low of 3.8 percent in Southeast England and London. The 1929 unemployment rate in Southern England was 6.4 percent, compared to 12.9 percent unemployment in Northern England and Wales. 


\section{Table 10: Average Unemployment Rates Among Insured Workers:}

Selected Industries, 1924-29

Source: Mitchell and Deane (1962)

\begin{tabular}{|l|l|}
\hline Industry & Unemployment Rate \\
\hline Coal Mining & $15 \%$ \\
\hline Iron \& Steel & $21 \%-25 \%^{16}$ \\
\hline Shipbuilding & $30 \%$ \\
\hline Cotton Textiles & $14 \%$ \\
\hline Total & $11 \%$ \\
\hline
\end{tabular}

This concentration of unemployment in the North differs sharply from prewar patterns, in which unemployment was high in London (7.8 percent) and low in Wales and Scotland (3.1 percent and 1.8 percent, respectively). This regional concentration raised the marginal value of unemployment benefits because local housing subsidies raised the costs of relocating from high unemployment regions. BK note that rent control and housing subsidies were introduced after World War I and that these subsidies were lost once a household relocated.

The combination of large negative sectoral shocks to Britain's traditional industries, high regional concentration of industry, and low worker mobility suggests that workers experienced large negative shocks to their wages and faced high relocation costs if they moved to regions with better employment opportunities. These factors raised the marginal value of high, permanent unemployment insurance benefits and thus changed the incentives facing workers in these industries. High benefits, low market wages, and high relocation costs could

\footnotetext{
${ }^{16}$ The first number is the average for Steel Melting and Iron Pudding, and Iron and Steel Rolling and Forging. The second number is the average for General Engineering: Engineers' Iron and Steel Founding.
} 
have led some of these workers to prefer unemployment during the interwar period. But while this combination of factors was present during the interwar period, it was not present during the post-World War II period.

A key difference between the two postwar periods is that sectoral shocks appear to be much smaller after World War II. In particular, increased foreign competition, which significantly affected Britain's staples industries after World War I, did not affect British industry after World War II. For example, Broadberry (1997, p. 13) argues that Britain emerged from WWII highly dependent on its home and Commonwealth producers and that this enabled Britain to avoid competition with US and German producers until Britain joined the EEC in 1973. These large differences in postwar sectoral shocks between the 1920s and 1950s along with policies that distorted worker relocation suggest that the big employment differences between the interwar period and the immediate post-WWII period may be consistent with government policies that changed the incentive to work.

\section{Summary and Conclusion}

The UK was depressed for 20 years between the end of World War I and the start of World War II. During this period output per adult was roughly 20 percent below its preWorld War I trend. This decrease was entirely due to labor input, rather than decreases in productivity or the capital stock. Labor input fell more than 25 percent, reflecting declines in both hours per worker and in employment.

Our analysis suggests that Keynes' views about the importance of Britain's declining export sectors during the interwar period were indeed correct - much of the employment loss

in Britain was concentrated in these industries. However, our analysis raises questions about 
Keynes' views of the causes of Britain's interwar depression. Keynes argued that imperfectly flexible wages, deflation, and an over-valued exchange rate caused Britain's interwar depression. We find that the standard Keynesian monetary/exchange rate explanation of this depression is unconvincing, however. Most of the decrease in output occurred before the negative monetary and exchange rate shocks, and the depression lasted much longer than can be reasonably explained by modern monetary business cycle theory. We also investigated the macroeconomic effects of real shocks, including a 15 percent cut in the workweek. This shock depressed hours per worker substantially and depressed output moderately, but should have led to a significant increase in employment. This prediction of employment growth stands in contrast to the observed 11 percent employment decrease.

We conclude that the key to unlocking the mystery of the UK interwar depression is finding a large, negative, persistent shock to labor supply. The theory should be able to account for depressed interwar employment and normal post-World War II employment, despite roughly the same level of unemployment benefits during both periods.

We find that the observed level of benefits correctly predicts the level of post-World War II UK employment. This leads us to conclude that unemployment benefits, combined with large, negative sectoral shocks and government policies that raised the cost of worker relocation may account for the interwar depression. The impact of benefits was higher during the interwar period, given the large negative shocks that hit Britain's export industries immediately after World War I. Benefits were particularly attractive to workers in export industries, because they experienced large negative shocks to their productivities and also faced high costs of leaving depressed regions due to local housing subsidy policies. Our future work will focus on quantitatively analyzing the implications of these shocks for the interwar period. 


\section{Appendix}

\section{A. The Prior Debate}

The prior debate on the importance of the UK unemployment benefits system in Britain's high interwar unemployment rate centered on the work of Benjamin and Kochin $(1979,1982)(B K)$ and the reactions of their critics. BK present qualitative and quantitative arguments that unemployment benefits raised UK unemployment. Qualitatively, they noted three aspects of the benefits system that could lead to high unemployment: insurance contributions were independent of either workers' or firms' past histories, benefits were independent of a worker's past wage, and benefits could be collected indefinitely and were payable for unemployment spells as short as one day. The lack of experience rating, the long-term availability of benefits, and eligibility based on very short spells suggest that both moral hazard and adverse selection problems could have been pervasive.

Benjamin and Kochin's (BK) quantitative arguments are based on three pieces of evidence. The best known piece of evidence is a time series regression of the aggregate unemployment rate regressed on the $B / W$ ratio and the deviation of output from trend in which the coefficient on benefits was sizeable and significantly positive. ${ }^{17}$ The $B / W$ regression coefficient indicates that the large increase in unemployment benefits raised the unemployment rate by as much as nine percentage points during the interwar period. The other two pieces of evidence are about differences in unemployment rates and benefits and/or eligibility

\footnotetext{
${ }^{17}$ Their main regression of unemployment on the ratio of benefits-to-average-wages and deviation of log output from trend is reproduced here:

$$
\begin{aligned}
U= & .19+18.3 *(B / W)-90.0 *\left(\log \left(Q / Q^{*}\right)\right. \\
& (2.64)(4.46) \quad(-8.30) \\
R^{2}= & .84, \bar{R}^{2}=.82, \mathrm{D}-\mathrm{W}=2.18, S E=1.90 .
\end{aligned}
$$
}


across demographic groups. BK documented that the juvenile unemployment rate was much lower than the adult unemployment rate, which they attribute to much lower juvenile unemployment benefits. They also documented that unemployment among married women fell substantially after the October 1931 Anomalies Legislation, which significantly raised married women's contributory requirements.

\section{The Criticisms of the Unemployment Benefits Explanation}

The unemployment benefits explanation has been discounted by interwar British scholars. For example, Eichengreen (1987, p. 182) notes, "Although Keynesians have conceded that some small portion of interwar unemployment may be explicable on these grounds, few have sympathy for the notion that the insurance system contributed significantly to the magnitude of the problem."

There have been four different criticisms of BK's analysis. One is that cross-sectional data do not support the unemployment benefits explanation (Eichengreen (1987)). Eichengreen notes that the unemployment benefits explanation predicts that individuals with high $B / W$ ratios should have had higher rates of unemployment. He evaluates this hypothesis by estimating a cross-sectional probit model of individual employment status on a constructed $B / W$ ratio for the individual and other variables and finds only a small, statistically insignificant relationship between unemployment and his estimate of the $B / W$ ratio. His test uses survey data collected in the London area during 1929-31 on age, sex, martial status, home ownership, employment status, wages and other sources of income, and actual and imputed unemployment benefits.

While a micro analysis could provide a strong evaluation of the unemployment benefits 
explanation, there are data problems with Eichengreen's constructed $B / W$ ratio that do not permit such a strong test. One drawback is the measure of the market wage for unemployed individuals, which Eichengreen estimates as unemployed individuals' own estimates of their normal market wage. ${ }^{18}$ This estimate will likely overstate the actual market wage because individuals who self-select to search tend to have a higher assessment of their market wage than individuals who are employed. This suggests that the estimated market wage for the unemployed is biased upwards. This bias would be expected to be particularly large for longterm searchers. In this regard, it is interesting to note that the original Beveridge (1945) report shows that the fraction of unemployed who had been unemployed for more than a year rose from $4.7 \%$ of the total in September of 1929 to $16.4 \%$ of the total by August of 1932 . This roughly corresponds to the period in which the data used by Eichengreen were collected.

A second drawback is the lack of explanatory power in a first-stage wage prediction regression for both the employed and the unemployed. To correct for selectivity bias in the probit regression, Eichengreen uses a predicted wage to construct the $B / W$ ratio, rather than his wage measures for the employed and unemployed. The problem here is that the predicted wage equation suffers from omitted variable bias and low explanatory power. As Eichengreen notes, the survey data do not include many of the standard wage equation variables, such as measures of human capital, years of experience, or the industry in which the individual works. Consequently, the $R^{2}$ from the wage regression is only 0.18 . Moreover, most of this explanatory power seems to be coming from relatively young workers: the $R^{2}$ for heads-ofhousehold is only 0.08 while that for nonheads-of-household is 0.20 . Since the policy provided very low benefits to young workers, the nonheads-of-household observations may not provide

\footnotetext{
${ }^{18}$ For employed individuals, Eichengreen uses their current reported earnings.
} 
much information about the incentive effect of unemployment benefits. This poor fit in the first stage wage regression for household heads suggests another possible source of bias in the coefficient estimates and may also lead to a large standard error on the $B / W$ coefficient in the probit regression.

The upward bias in the measured wage, along with the relatively poor fit in the first stage wage regression, may explain why Eichengreen found only a small and statistically insignificant relationship between unemployment and benefits. This suggests that Eichengreen's analysis does not provide convincing evidence against the unemployment benefits theory.

Hatton (1994) also argues that cross-sectional data do not support BK's thesis. He argues that $B / W$ ratios in cross-sectional data are too small to have raised unemployment. Hatton's analysis is based on survey data conducted by the Ministry of Labor in the late 1930s. The government was worried that unemployment benefits were too generous and asked unemployed individuals to compare their benefits to their previous wage. Table 11 summarizes these data.

The data show that a very small fraction of individuals received benefits that exceeded their previous wage and that a greater fraction of individuals were receiving benefits between 60 percent and 80 percent of their previous wage. Hatton's main point is that the fraction of workers with benefits close to or exceeding their previous wage was too small to support the unemployment benefits explanation.

The fact that few individuals had complete unemployment insurance replacement relative to their previous wage sheds no light on the unemployment benefits thesis. This is because these data miss the two key factors affecting the decisions of unemployed workers: the opportunity cost of working and the individual's current market wage - not the individ- 
ual's previous market wage - relative to the benefit. The higher the opportunity cost and the lower the current market wage, the more attractive is the unemployment benefit, irrespective of the individual's previous wage.

Table 11: Benefit-to-Wage Ratios for

Claimants to Insurance Benefits, 1937

\begin{tabular}{|l|l|l|l|l|}
\hline$B / W$ ratio & Men & Men & Women & Women \\
\hline Greater than & $18-20$ & $21-64$ & $18-20$ & $21-46$ \\
\hline 1.0 & 2.6 & 0.5 & 3.4 & 0.9 \\
\hline 0.8 & 6.5 & 2.0 & 8.2 & 4.4 \\
\hline 0.6 & 17.1 & 11.7 & 23.1 & 17.5 \\
\hline
\end{tabular}

There are good reasons to believe that the opportunity cost of working was high. Many of the individuals covered under the insurance program were manual laborers, which suggests that the disutility of working (e.g., coal mining) was high. This tends to reduce the level of the unemployment benefit necessary to keep individuals in non-market activity. There are also good reasons to believe that the current wage for many of these individuals may have been significantly lower that their past wage. Recent studies show that individuals who lose jobs during periods of large layoffs receive significantly lower wages for a number of years after the initial job loss. For example, Jacobson, Lalonde, and Sullivan (1993) report that high tenure workers earn wages that are about 25 percent lower than their previous wage five years after the loss of their previous employment. If this profile also characterized wages in the UK during the interwar period, then the replacement rate relative to individuals' current 
market wages would be considerably higher than those presented in Table 11. We conclude that these data do not reject the unemployment benefits explanation.

The second criticism of BK is their interpretation of the change in unemployment among married women after their contributory requirements rose. Collins (1982) argues that the higher contributory requirement may have led married women to leave the unemployment roles by dropping out of the labor force, rather than becoming employed. In the absence of individual data about the labor force status of married women, Collins' argument suggests that there is an alternative interpretation of the fact that unemployment among married women dropped relative to single women and males. This is not evidence against BK's unemployment benefits explanation, but this alternative interpretation does weaken BK's empirical argument about unemployment among married women.

The third criticism is the robustness of their regression results. Ormerod and Worswick (1982) document that the coefficient on the $B / W$ variable in BK's regression equation is sensitive to changes in the sample period, and they argue that this sensitivity raises questions about BK's conclusions. Other studies find that the value of the $B / W$ coefficient in BK's regression is similar to the value found in studies for the post-WWII period. In our view the Ormerod-Worswick criticism - and more generally the issue of parameter instability is uninformative since the regression coefficients would indeed be expected to change with changes in the sample period. This is because the BK regression was not derived explicitly from economic theory and thus is probably best viewed as a reduced form relationship rather than an explicit structural relationship. In particular, an equation for the unemployment rate that was derived from dynamic theory would not involve just a static relationship between the aggregate unemployment rate and the current unemployment benefit, but would also 
involve dynamic effects. ${ }^{19}$ While we don't find parameter instability a convincing rejection of BK's conclusions, it does highlight the importance of assessing the impact of these high unemployment benefits using a formal economic model.

The fourth and most important criticism of BK has been made by Metcalf, Nickell and Floros (1982). They argue that unemployment benefits are not the key to the interwar British depression because the unemployment rate in the 1950s was much lower than in the 1930s, even though benefit levels during these periods were about the same. Table 9 shows the replacement rate, two measures of the unemployment rate, and employment per adult during the interwar period and during the 1950s. The data for the 1950s replacement rate are from Maki and Spindler (1975). ${ }^{20}$ The replacement rate falls from about 0.56 in the 1930s to 0.38 in the 1950s. This suggests that benefits in the $1950 \mathrm{~s}$ were lower than those in the 1930s, but about the same as those in the 1920s.

Benjamin and Kochin (1982) responded to this criticism by arguing that changes in the composition of insured individuals and changes in the reporting of short-term unemployment spells after World War II can explain the apparent drop in postwar unemployment. In particular, BK argue that the pool of workers who were insured after WWII had expanded

\footnotetext{
${ }^{19}$ For example, in a dynamic model of unemployment, such as Mortensen and Pissarides (1994), the surplus to be split between a worker and an employer from a job is stochastic. Hence, if the welfare level of the unemployed was suddenly increased due to an increase in the unemployment insurance benefit, then those workers in jobs with marginal levels of surplus would be induced to immediately quit their jobs. This would not be the only effect since the unemployment rate could continue to rise as workers initially in jobs with a sufficiently high level of surplus experienced negative shocks to the surplus value of their jobs. This dynamic response is not captured by BK's static regression, nor can this effect be captured by simply adding some lagged values of the benefit level to the equation. It is not at all surprising that a misspecified regression using a short sample is sensitive to adding or dropping observations.

${ }^{20}$ There seems to be a surprising degree of lack of consensus as to the level of the benefit-to-wage ratio in the postwar period. Metcalf, Nickell, and Floros (1982) report numbers that are much closer to the interwar level (.43 for 1951-57 and .54 for 1958-65). We have gone with Maki and Spindler's (1975) numbers, which they cite as coming from the Department of Health and Social Security. Obviously, using Metcalf, Nickell, and Floros' (1982) numbers would only sharpen the criticism.
} 
considerably to include many nonmanual workers who do not experience the same unemployment risks. They also note that post-World War II unemployment statistics do not count workers experiencing very short-run spells. These two points raise questions about comparing unemployment rates before and after World War II, but they do not address the implications of the relative constancy of the replacement rate for employment: the employment rate returned to its pre-World War I level of 0.68 by the 1950 s.

Overall, our assessment is that the empirical focus of the debate makes it hard to draw conclusions about the effects of unemployment benefits. This is particularly noteworthy regarding the static relationship assumed between benefits and unemployment, when standard theory predicts a dynamic relationship between these variables. For example, in a dynamic model of unemployment, such as Mortensen and Pissarides (1994), the surplus to be split between a worker and an employer from a job is stochastic. Hence, if the welfare level of the unemployed was suddenly increased due to an increase in the unemployment insurance benefit, then those workers in jobs with marginal levels of surplus would be induced to immediately quit their jobs. This would not be the only effect since the unemployment rate could continue to rise as workers initially in jobs with a sufficiently high level of surplus experience negative shocks to the surplus value of the individual's job. There are additional dynamic effects coming through search. In particular, an individual's reservation wage and search intensity depends on their level of assets, which implies that the benefit/wage ratio is not a sufficient statistic for determining employment status (see Gomes, Greenwood, and Rebelo, 2001). These dynamic responses are not captured either by BK's static regression or by the static regressions run by BK's critics.

In summary, the lack of an appropriate theoretical foundation undercuts the force of 
the arguments on both sides of this debate and leads us to use a general equilibrium model that highlights the incentive effects of benefits and the dynamic equilibrium relationship between benefit changes and employment.

\section{B. Notes on the Data Presentation}

1. Unless otherwise specified the data are from Feinstein (1972): National Income, Expenditure and Output of the United Kingdom 1855-1965.

2. Data on the U.S/U.K. nominal exchange rate, the U.K. money stock, and the U.S. GNP deflator are from Friedman and Schwartz (1982): Monetary Trends in the United States and the United Kingdom.

3. Data on labor union membership, number of days lost through disputes, and average hours worked are from Mitchell and Deane (1962): British Historical Statistics.

4. Data on nominal hourly wages by employment category are from British Labor Statistics: Historical Abstract 1886-1968.

5. The data on French interwar output are from Mitchell and Deane (1962).

6. Data on unemployment benefits come from Maki and Spindler (1975). The Effect of Unemployment Compensation on the Rate of Unemployment in Great Britain, Oxford Economic Papers.

7. Data on the monthly retail price index, the wage index, the percentage of insured workers employed and unemployed, and the industrial production index are from Capie and Collins (1983). 
8. World GDP and population data are from Maddison (1995): Monitoring the World Economy. The countries in our measure of world output are Australia, Austria, Belgium, Canada, Denmark, Finland, France, Germany, Italy, Japan, Netherlands, New Zealand, Norway, Sweden, Switzerland, USA, Spain, Argentina, Brazil, Chile, India. 


\section{References}

[1] Aldcroft, Derek (1970) The Inter-War Economy: Britain 1919-1939. London: Batsford.

[2] Aldcroft, Derek (1986) The British Economy, vol. 1: Years of Turmoil, 1920-1951, Sussex: Wheatsheaf Books.

[3] Alford, B.W.E. (1981) "New Industries for Old? British Industry Between the Wars," in Floud and McCloske (eds) The Economic History of Britain since 1700, vol. 2, Cambridge: Cambridge University Press.

[4] Benjamin, Daniel and Levis Kochin (1979) "Searching for an Explanation of Unemployment in Interwar Britain", Journal of Political Economy, no. 3, 441-478.

[5] Benjamin, Daniel and Levis Kochin (1982) "Unemployment and Unemployment Benefits in Twentieth-Century Britain: A Reply to Our Critics", Journal of Political Economy, vol. 90 , no. $2,410-436$.

[6] Beveridge, William (1945) Full Employment in a Free Society, New York: Norton \& Co.

[7] British Labor Statistics Historical Abstract 1886-1968. London: Her Majesty's Stationary Office (1971).

[8] Broadberry, S.N. (1997) The Productivity Race : British Manufacturing in International Perspective, 1820-1990, Cambridge: Cambridge University Press.

[9] Burns, Eveline (1941) British Unemployment Programs: 1920-1938, Washington: Social Science Research Council. 
[10] Capie, Forrest and Michael Collins (1983) The inter-war British economy: A statistical abstract, Manchester: Manchester University Press.

[11] Cogan, John F. (1981) "Fixed Costs and Labor Supply", Econometrica, vol. 49, No. 4, 945-963.

[12] Cole, Harold L. and Lee E. Ohanian (1999) "The Great Depression in the United States from a Neoclassical Perspective", Federal Reserve Bank of Minneapolis Quarterly Review, Winter, 3-21.

[13] Cole, Harold L. and Lee E. Ohanian (2001a) "A Re-examination of the Contribution of Money and Banking Shocks to the U.S. Great Depression" in Ben Bernanke and Ken Rogoff, eds. Macroeconomics Annual, NBER, MIT Press, Cambridge, MA.

[14] Cole, Harold L. and Lee E. Ohanian (2001b) "New Deal Policies and the Persistence of the Great Depression: A General Equilibrium Analysis", Staff Report 597, Federal Reserve Bank of Minneapolis.

[15] Collins, Michael (1982) "Unemployment in Interwar Britain: Still Searching for an Explanation," Journal of Political Economy, vol. 9(2).

[16] Broadberry, S.N. (1997) The Productivity Race, Cambridge: Cambridge University Press.

[17] Deacon, Alan (1976) In Search of the Scrounger: The Administration of Unemployment Insurance in Britain 1920-31, Occasional Papers on Social Administration, No. 60, London: G. Bell and Sons. 
[18] Dimsdale, N. H. (1981) "British Monetary Policy and the Exchange Rate, 1920-38", in The Money Supply and the Exchange Rate, W.A. Eltis and P. Sinclair, eds. Oxford University Press, 306-349.

[19] Eichengreen, Barry (1987) "Unemployment in Interwar Britain: Dole or Doldrums?" Oxford Economic Papers 39, 597-623.

[20] Feinstein, Charles (1972) National Income, Expenditure and Output of the United Kingdom 1855-1965, Cambridge: Cambridge University Press.

[21] Friedman, Milton and Anna J. Schwartz (1982) Monetary trends in the United States and the United Kingdom, their relation to income, prices, and interest rates, 1867-1975, Chicago: University of Chicago Press.

[22] Garside, W. R. (1990) British Unemployment 1919-39, Cambridge: Cambridge University Press.

[23] Gomes, Joao, Jeremy Greenwood and Sergio Rebelo (2001) "Equilibrium Unemployment," forthcoming in the Journal of Monetary Economics.

[24] Hansen, Gary (1985) "Indivisible Labor and the Business Cycle", Journal of Monetary Economics, 16 (3), 309-327.

[25] Hatton, Timothy (1994) "Unemployment and the Labor Market in Inter-War Britain" in The Economic History of Britain since 1700: volume 2, 1860-1939, Roderick Floud and Donald McCloskey, eds. Cambridge: Cambridge University Press. 
[26] Jacobson, Louis, Robert LaLonde, and Daniel Sullivan (1993) "Earnings Losses of Displaced Workers", The American Economic Review, vol. 83, No. 4, 685-709.

[27] Keynes, John M. (1932) Essays in Persuasion, New York: Harcourt, Brace and Company.

[28] Ljungqvist, Lars and Thomas Sargent (1998) "The European Unemployment Dilemma," Journal of Political Economy, 106(3) (June): 514-50.

[29] Maki, Dennis and Spindler (1975) "The Effect of Unemployment Compensation on the Rate of Unemployment in Great Britain," Oxford Economic Papers, 27, No. 3 (November): $440-54$.

[30] Maddison, Angus (1995) Monitoring the World Economy, 1820-1992, Paris: Development Centre of the Organisation for Economic Co-operation.

[31] Mitchell, B.R. and Phyllis Deane (1962) Abstract of British historical statistics, Cambridge: Cambridge University Press.

[32] Metcalf, David, Stephen Nickell and Nicos Floros (1982) "Still Searching for an Explanation of Unemployment in Inter-war Britain," Journal of Political Economy, vol. $9(2)$.

[33] Moggridge, Donald (1972) British Monetary Policy, 1924-31. The Norman Conquest of \$4.86, Cambridge: Cambridge University Press.

[34] Mortensen, Dale and Chris Pissarides (1994) "Job Creation and Job Destruction in the Theory of Unemployment," Review of Economic Studies; 61(3), July 1994, pages 397415. 
[35] Ormerod, P.A. and G.D.N. Worswick (1982) Searching for an Explanation of Unemployment in Interwar Britain: A Comment, Journal of Political Economy, vol. 9(2).

[36] Rogerson, Richard (1988) "Indivisible Labor, Lotteries, and Equilibrium, Journal of Monetary Economics, 21 (1), 3-16.

[37] Youngson, A.J. (1967) Britain's Economic Growth: 1920-1966, London: George Alwin and Urwin. 
Figure 1: Output in UK and Rest of World

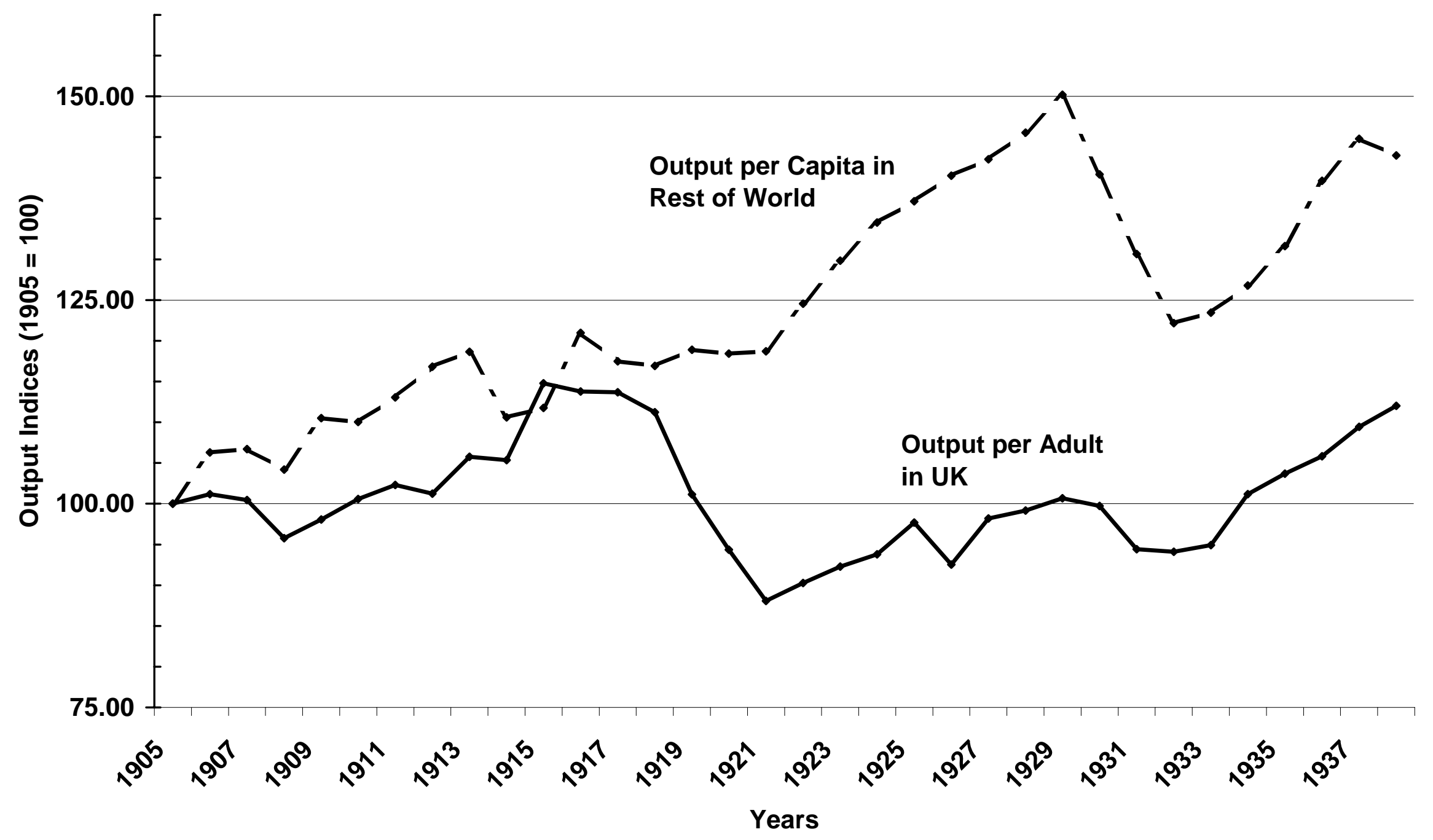


Figure 2: Real Wages Relative to Productivity

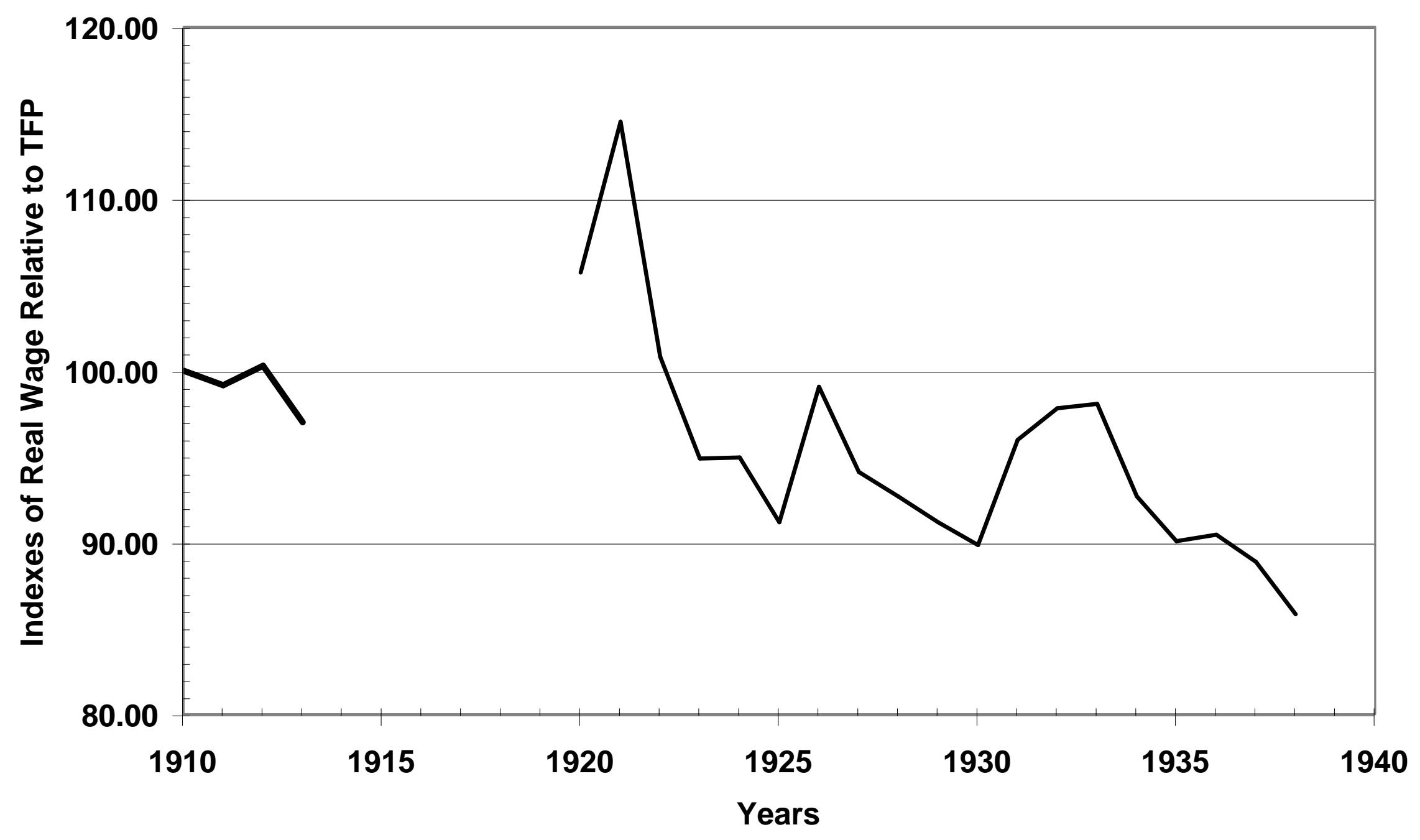


Figure 3: Unemployment Benefits/Average Wage

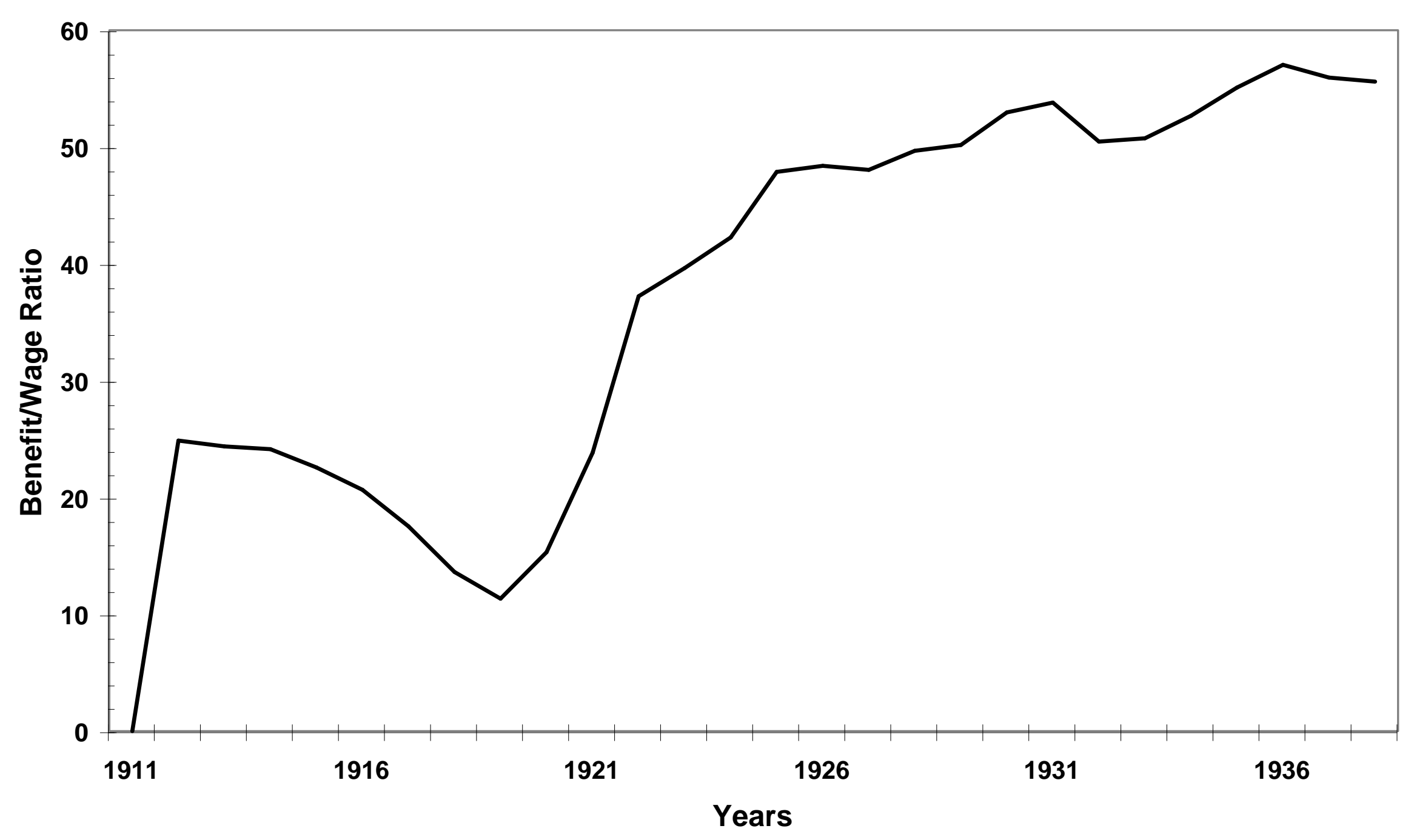

